\title{
NILAI-NILAI PENDIDIKAN MULTIKULTURAL NOVEL DIFFERENT: KETIKA PERBEDAAN BUKAN SEBUAH PENGHALANG KARYA IRMA T. LESTARI
}

\author{
Setijani \\ SDN Ploso V Surabaya \\ Setijani535@yahoo.com
}

\begin{abstract}
ABSTRAK
Penelitian ini bertujuan mendeskripsikan dan menganalisis nilainilai pendidikan: (1) menghargai perbedaan Suku; (2) menghargai perbedaan agama; (3) menghargai perbedaan ras; dan (4) menghargai perbedaan budaya yang terkandung dalam novel Different Penelitian ini menggunakan jenis kualitatif, sedangkan pendekatan yang digunakan adalah sosiologi sastra. Objek penelitiannya adalah Novel: Different dan analisis datanya menggunakan model interakcrive dari Milles \& Huberman. Hasil penelitian menunjukkan bahwa nilai-nilai pendidikan multikultural novel Different adalah mencakup beberapa hal. (1) Nilai menghargai perbedaan suku tercermin dalam sikap saling menghormati dan saling menghargai antar tokoh suku atau etnis China dengan tokohtokoh suku Jawa dan Bali. Mereka dapat hidup damai dan rukun mulai SD sampai perguruan tinggi; (2) Nilai menghargai perbedaan agama tercermin dalam sikap saling menghormati dan saling menghargai antar tokoh dalam novel, antara tokoh dengan orang tuanya, antara tokoh dengan dosen dan teman-temannya yang berbeda agama; (3) Nilai menghargai perbedaan ras tercermin dalam sikap saling menghormati dan saling menghargai antara tokoh yang memiliki ciri-ciri fisik China dengan tokoh yang memiliki ciri-ciri fisik suku Jawa dan Bali; dan (4) Nilai menghargai perbedaan budaya tercermin dalam sikap saling menghormati dan saling menghargai antara tokoh yang memiliki budaya China yang beragama Konghucu dengan tokoh yang memiliki budaya Jawa yang berama Islam, dan tokoh yang memiliki budaya Bali yang beragama Hindu dan Kristen.
\end{abstract}

Kata Kunci: Nilai-nilai pendidikan, multikultural, novel Different

ABSTRACT

This research is aimed to describe and analyze the value of education: (i) to appreciate the difference ethnicity; (2) respect differences religion; (3) respect differences race; and (4) respect differences of culture depicted in the novel Different: ketika perbedaan bukan sebuah penghalang writen by Irma T. Lestari. This research is a qualitative research, whereas the approach used is sociology of literature and the object of the research is Novel: Different: ketika perbedaan bukan sebuah penghalang written by Irma T. Bieber, and the data analysis uses interactive model from Milles and Huberman. The result of the research showed that the education values of multicultural depicted in the novel Different: ketika perbedaan bukan sebuah penghalang written by Irma T. Bieber is: (i) the value appreciate the difference reflected in mutual respect and mutual respect among the figure tribe or ethnic Chinese with the figures of Javanese and Balinese. They can live in peace and harmony from elementary to college; (2) Value appreciate the difference religions reflected in mutual respect and 
mutual respect among the characters in the novel, between the characters with their parents, between the characters with lecturers and friends with different religions; (3) Value appreciate differences race reflected in the mutual respect and mutual respect between leaders who have the physical characteristics of China with the character that has the physical characteristics of Javanese and Bali; and (4) Value appreciate differences culture reflected in mutual respect and mutual respect between the figures who have Chinese culture and have a Confucius religion with the figures who have Javanese culture and have a Islamic religion, and with the figures who have Balinese culture and have a Hindu and christen religion cultural figures who have Balinese Hindus and Christians.

\section{Keywords: the educational values, multicultural, novel Different}

PENDAHULUAN terasa sangat penting mengingat masalah-masalah toleransi antarwarga negara di Indonesia kian memburuk. Kasus penjarahan, pemerkosaan, dan penyiksaan etnis China dalam peristiwa kerusuhan "Juli 2008" di Jakarta menunjukkan betapa buruknya toleransi bangsa Indonesia terhadap kaum minoritas, yakni etnis China. Kasus bom Bali yang dilakukan oleh Amrozi dan kawan-kawan pada 12 Oktober 2002 juga sempat mencoreng nama baik Indonesia di mata internasional karena dinilai betapa kejam dan sadisnya umat Islam Indonesia terhadap umat lain meskipun para pelaku tidak mewakili umat Islam Indonesia. Kasus "Sampit" Kalimantan yang mempertontonkan ke publik perang keji antara suku dayak dengan suku Madura pendatang. Juga kasus "Poso" yang memperlihatkan kekejaman umat Islam terhadap kaum Nasrani, kasus pertikaian sesama umat islam di Pamekasan Madura, dan kasus Tolikara Papua. Seperti diketahui, sekelompok orang tak dikenal melakukan pembakaran mushola di Tolikara Papua ketika jamaah di dalamnya bersiap Sholat Idul Fitri 1436 H (2015 M). Atas kejadian itu, warga yang hendak melakukan shalat $i d$ di Lapangan Koramil Tolikara terpaksa membubarkan diri karena takut menjadi sasaran amuk massa. Selain mushola, beberapa kios dan rumah warga juga dibakar oleh pelaku tak bertanggung jawab tersebut.

Peristiwa-peristiwa tersebut menunjukkan bahwa toleransi sesama warga negara di negara kita masih sangat memprihatinkan. Masalah-masalah pertikaian karena perbedaan suku, agama, ras, dan budaya masih sering terjadi bahkan masalah tersebut sering dijadikan komoditas bagi pihak-pihak yang ingin mengacaukan keamanan nasional. Hal itu dilakukan karena mereka menyadari bahwa bangsa Indonesia mudah "terbakar" jika pemicunya dibungkus ke dalam keempat masalah tersebut. Untuk itulah diperlukan penanaman nilainilai pendidikan multikultural kepada bangsa Indonesia, khususnya generasi muda, melalui berbagai cara dan media. Satu di antaranya melalui novel.

Menurut Burhan (1995:9), novel adalah sebuah prosa fiksi yang panjangnya cukup, artinya tidak terlalu panjang, namun juga tidak terlalu pendek. Lebih lanjut Burhan (1995: 4) mengatakan bahwa "novel menawarkan sebuah dunia yang berisi model kehidupan yang diidealkan, dunia imajiner yang dibangun melalui unsur intrinsik 
seperti peristiwa, plot, tokoh, latar, dan sudut pandang yang tentu saja semuanya bersifat imajiner". Dikatakan menawarkan model kehidupan yang diidealkan, karena di dalam novel terdapat suatu model kehidupan yang menampilkan aspek kehidupan manusia secara mendalam. Sesuai dengan pernyataan Atar Semi (1993: 32), yaitu "novel merupakan karya fiksi yang mengungkapkan aspek kemanusiaan yang lebih mendalam dan disajikan dengan halus".

Novel sebagai media pendidikan termasuk salah satu kategori buku suplemen dapat berfungsi sebagai bahan pengayaan bagi peserta didik, baik yang berhubungan dengan pelajaran atau pun yang tidak, dapat menambah bekal kepada peserta didik untuk memantapkan aspekaspek kepribadiannya. Keberadaan buku suplemen dapat memberikan peluang kepada anak untuk memenuhi minat-minat individual mereka. Melalui buku suplemen yang menarik bagi anak-anak, diharapkan akan menambah perbendaharaan pengetahuan, keterampilan, dan sikap-sikap baru yang menunjang kemantapan kepribadiannya. Oleh karena itu, novel bisa dijadikan sebagai salah satu perantara untuk mengantarkan anak menuju potensi diri yang sesungguhnya, dan sekaligus membentuk bagian-bagian tertentu pada karakter dan kepribadiannya, termasuk karaktermenghargai perbedaan suku, ras, pendidikan, agama, maupun budaya. Dengan kata lain novel dapat menjadi sarana pendidikan multikultural.

Novel Different: Ketika Perbedaan Bukan Sebuah Penghalang karya Irma T. Lestari merupakan novel yang sarat akan pendidikan multikultural, diangkat dari kisah nyata, disajikan dengan bahasa yang sederhana yang memberikan manfaat nyata dan riil bagi setiap pembacanya. Novel ini menceritakan kisah persahabatan tiga anak manusia dari Pulau Dewata: Noura, Alika, dan Gugun. Mereka berasal dari latar belakang keyakinan berbeda. Noura beragama Islam, Alika berasal dari keluarga Hindu dan Katolik, sedangkan Gugun dibesarkan dalam keluarga Tionghoa yang beragama Konghucu.

Permasalahan muncul ketika Noura menghadapi kenyataan tragedi bom Bali. Ia pun mulai gamang dengan keyakinannya. Di sisi lain, banyak hal terjadi yang menguji sikap saling toleransi di Bali, khususnya antara warga pribumi dengan umat muslim. Salah satunya adalah pelarangan memakai jilbab di sekolah-sekolah. Kebimbangan juga menerpa hati Alika yang dibesarkan dalam keluarga yang beda keyakinan. Ia harus memilih salah satu keyakinan kedua orang tuanya yang akan dianutnya tanpa menyakiti salah satu dari mereka.

Berbeda dengan Noura dan Alika yang memiliki permasalahan terkait keyakinan, Gugun memiliki masalah yang sedari kecil belum dapat ia selesaikan. Perasaan cinta pada teman kecilnya di SD kian hari makin menjadi tanpa berani ia ungkapkan. Mereka dapat menyelesaikan masalah masing-masing meskipun diantara mereka berbeda ras dan keyakinan. Mereka menjalin ikatan persahabatan yang sangat intim di atas perbedaan. Kisah mereka layak dicontoh oleh generasi muda Indonesia dalam hidup bersama ditengah-tengah perbedaan ras, suku, agama, dan budaya.

Novel Different merupakan novel yang layak sebagai media pembelajaran penanaman nilai-nilai multikultural dengan menyajikan cerita yang diangkat dari kisah nyata tentang bagaimana hidup bersama, rukun, damai ditengah-tengah perbedaan ras, agama, suku, dan budaya 
diantara para pemeran tokoh dalam novel tersebut. Untuk itulah peneliti tertarik menganalisis nilai-nilai pendidikan multikultural novel Different ini.

Fokus utama penelitian ini adalah nilai-nilai pendidikan multikultural menghargai perbedaan suku, agama, ras, dan budaya apa saja yang terdapat dalam novel Different.

\section{METODE}

Jenis penelitian yang digunakan adalah kualitatif deskriptif. Penelitian ini menggunakan pendekatan sosiologi sastra. Sumber datanya adalah dokumen novel. Objek penelitiannya nilai-nilai pendidikan multikultural dalam novel, meliputi nilai pendidikan dalam menghargai perbedaan suku, agama, ras, dan budaya yang terkandung dalam novel.

Pengumpulan data dengan studi pustaka tentang referensi yang terkait. Data dikumpulkan dengan pembacaan novel objek studi secara cermat, terarah, dan teliti. Pada saat melakukan pembacaan tersebut, peneliti mencatat data-data tentang nilai-nilai pendidikan multikultural yang ditemukan dalam novel tersebut. Analisis data menggunakan model analisis interaktif dari Milles dan Huberman.

\section{PEMBAHASAN Nilai Pendidikan Menghargai Perbedaan Suku}

Nilai pendidikan menghargai perbedaan suku yang terkandung dalam novel dibuktikan dalam kutipan berikut.

"Biasanya orang-orang China macam Gugun ini bersekolah di sekolah elit yang didominasi kalangan mereka sendiri. Buatku orang-orang China itu seperti kalangan atas yang tidak terjangkau oleh orang sederhana macam diriku dan keluargaku. Jadi, bila tiba-tiba ada orang China mau bersekolah di SD Negeri yang dipenuhi makhluk buluk seperti diriku dan temantemanku jelas dia akan sangat menarik perhatian." (Lestari, 2015:38)

Kutipan tersebut menggambarkan bahwa Naura sangat menghargai teman akrabnya bernama Gugun dengan nama asli Gunawan. Gugun adalah satu-satunya siswa etnis China di SD tempat Naura dan Gugun sekolah, teman lainnya semuanya adalah etnis Jawa dan Bali. Menurut Naura biasanya orang-orang etnis China bersekolah di sekolah-sekolah elit yang didominasi oleh kalangan mereka sendiri. Menurut Naura, orang-orang China itu seperti kalangan atas yang tidak terjangkau oleh orang sederhana macam dirinya dan keluarganya. Jadi, jika tiba-tiba ada orang China mau bersekolah di SD Negeri tempat Naura dan teman-temannya sekolah, jelas Gugun menurut Naura akan sangat menarik perhatian.

Selain satu-satunya orang Tionghoa, Gugun juga satu-satunya siswa yang memeluk agama Konghucu di SDN tempat Naura sekolah. Namun demikian Gugun tidak mengalami kesulitan dalam bergaul dengan teman-temannya. Menurut Naura, Gugun semakin menarik karena dia sangat ramah dan senang tersenyum pada orang- orang di sekitarnya. Dia tak pernah membatasi diri dalam pergaulannya. Dia bisa 
berteman dengan siapa saja. Sifatnya yang ramah itu tentu saja makin membuatnya terlihat menarik di mata Naura dan teman-temannya.

Semula Naura mengira jika orang-orang berkulit putih dan bermata sipit seperti Gugun pasti akan berlagak sombong, bahkan cenderung pemilih dalam mencari teman. Tapi semua perkiraan Naura salah, Gugun semakin menarik karena dia sangat ramah dan senang tersenyum pada orang-orang di sekitarnya. Dia tak pernah membatasi diri dalam pergaulannya. Dia bisa berteman dengan siapa saja. Sifatnya yang ramah itu tentu saja makin membuatnya terlihat menarik di mata Naura dan teman-temannya. Hal tersebut tampak pada kutipan berikut.

"Awalnya, aku mengira jika orang-orang berkulit putih dan bermata sipit seperti dia pasti akan berlagak sombong, bahkan cenderung pemilih dalam mencari teman. Tapi semua perkiraanku salah, Gugun semakin menarik karena dia sangat ramah dan senang tersenyum pada orang-orang di sekitarnya. Dia tak pernah membatasi diri dalam pergaulannya. Dia bisa berteman dengan siapa saja. Sifatnya yang ramah itu tentu saja makin membuatnya terlihat menarik di mata kami, temantemannya. Sayangnya Gugun tidak sekelas dengan saya, tetapi sekelas dengan Alika." (Lestari, 2015:38-39).

Menurut Naura, sebelum bertemu dengan Gugun, ia sering mendengar celotehan orang-orang bahwa orang China pelit-pelit. Naura ikut meyakini pameo tersebut karena tidak pernah bergaul dengan orang China. Di Bali, menurut Naura orang China kebanyakan adalah pengusaha dan pemilik toko-toko besar. Tetapi dari kisah teman-teman Naura yang sekelas dengan Gugun, Naura menyangsikan pameo dan pendapatnya tentang orang China tersebut. Naura merasa semakin sadar bahwa Gugun tidak seperti orang-orang China yang selama ini sering dibicarakan orang.

Teman-teman Naura yang sekelas dengan Gugun bercerita pada Naura bahwa Gugun sering membawakan makanan ringan dengan merk terkenal dari toko orang tuanya kepada teman-temannya di kelas. Hal ini membuktikan bahwa Gugun bukanlah termasuk orang yang pelit sebagaimana anggapan kebanyakan orang terhadap etnis China.

Gambaran Gugun sebagaimana dideskripsikan Naura di atas menunjukkan bahwa (1) Gugun berhati mulia, mampu memandang perbedaan suku bukan menjadi penghalang dalam menuntut ilmu dan berteman, demikian orang tua Gugun yang memperkenankan Gugun bersekolah di SD Negeri yang didominasi anak-anak Jawa dan Bali. Tidak satu pun siswa yang beretnis China kecuali Gugun. Sikap Gugun dan orang tuanya itu patut menjadi tauladan bagi seluruh warga bangsa Indonesia bahwa meskipun etnis minoritas asalkan dapat beradaptasi dengan budaya etnis mayoritas maka perbedaan suku dan ras bukan menjadi penghalang dalam bergaul dan mencapai cita-cita; (2) Sikap Naura, Alika, dan teman-teman sekelas Alika terhadap Gugun juga layak menjadi tauladan. Mereka menerima dengan tulus berteman dengan Gugun tidak dilihat karena suku atau etnis Chinanya, juga bukan karena Gugun gemar memberi makanan ringan, tetapi karena kemampuan Gugun dalam bergaul dengan teman-temannya. Jadi menilai orang seharusnya bukan dari suku atau etnisnya, tetapi dari 
kualitas pribadi dan kemampuannya. Sebagaimana dikemukakan Naura dalam kutipan berikut.

"Alika dan Gugun telah mengajarkan kepadaku banyak hal. Bahwasanya, kita tidak boleh begitu saja menghakimi seseorang ataupun menyamaratakan semua orang hanya dari bentuk fisik, suku, ataupun budaya. Alika telah mengajarkanku bahwa tidak semua anak yang memiliki orang tua berbeda agama tidak bisa menjalankan ibadah dengan benar karena bingung menentukan pilihan mereka. Gugun telah mengajarkanku bahwa tidak semua orang China itu pelit. Dari mereka berdualah, aku belajar untuk benar-benar menilai seseorang dari kualitas pribadi dan kemampuannya.” (Lestari,2015:41)

Bagi Naura memperjuangkan prinsip hidupnya yang menghargai keragaman budaya, agama, etnis, dan ras demi kerukunan dan kedamaian antara umat bukanlah merupakan perjuangan yang mudah. Ujian berat dialami ketika sebuah noktah hitam yang tidak akan pernah hilang dan akan terus membayangi Naura seumur hidupnya. Sebuah kejadian yang akan terus dikenang dalam sejarah kelam Indonesia, umat Islam, dan masyarakat Pulau Bali. Sebuah kejadian yang mengubah hidup banyak orang, yakni bom Bali I tgl. 12 Oktober 2002. Sebagaimana dikemukakan Naura dalam kutipan berikut.

"Prinsipku tersebut rupanya mengalami ujian berat. Aku yang mencoba untuk tidak menghakimi seseorang dari suku, ras, ataupun agamanya justru dihakimi seperti itu. Kehidupanku berjalan dengan baik pada awalnya. Semua terlihat harmonis, aku punya keluarga yang bahagia, teman-teman yang berbeda tapi menyenangkan, dan tentu saja aku punya tanah kelahiran yang sangat kubanggakan. Segalanya berjalan normal hingga munculkejadian itu, sebuah noktah hitam yang tidak akan pernah hilang dan akan terus membayangiku seumur hidup. Sebuah kejadian yang akan terus dikenang dalam sejarah kelam Indonesia, umat Islam, dan masyarakat Pulau Bali. Sebuah kejadian yang mengubah hidup banyak orang, bom Bali I tgl. 12 Oktober 2002”. (Lestari, 2015:41-42).

\section{Nilai Pendidikan Menghargai Perbedaan Agama}

Nilai pendidikan menghargai perbedaan agama yang terkandung dalam novel dibuktikan pada kisah Alika yang sejak kecil sudah memperhatikan kedua orang tuanya berbeda agama. Kedua orang tuanya memperkenalkan agama yang diyakininya masing-masing kepada Alika. Ayahnya beragama Hindu dan ibunya beragama Kristen. Awalnya menurut Alika terlihat mudah, toh masih kecil, jadi Alika tidak punya beban pikiran apapun untuk memilih salah satu. Alika tahu ia perlu belajar keduanya. Masalah pilihan, tunggu saat nanti Alika dewasa. Tapi makin hari, saat usia bertambah, ia makin sadar bahwa permasalahannya tidak sesederhana yang dipikirkan. Alika mendapat pelajaran agama Hindu dari ayahnya, selain itu juga mendapat dari sekolah. Pelajaran agama Kristen hanya Ia dapatkan dari ibunya. Hal tersebut tampak pada kutipan berikut. 
"Saat masih kecil, aku dan mungkin anak-anak seusiaku memiliki lingkungan yang sama, masih terbilang belum cukup dewasa untuk mengerti agama. Kami hanya bisa melihat dan memperhatikan kedua orang tua kami saling beribadah menurut kepercayaannya masing- masing. Kami diperkenalkan oleh mereka pada kedua agama yang berbeda itu. Awalnya terlihat mudah, toh kami masih kecil, jadi kami tidak punya beban pikiran apapun untuk memilih salah satu. Yang kami tahu kami perlu belajar keduanya. Masalah pilihan, tunggu saat nanti kami dewasa. Tapi makin hari, saat usia kami bertambah, kami makin sadar bahwa permasalahannya tidak sesederhana yang kami pikirkan.” (Lestari, 2015:61-62).

Dalam menghadapi kebimbangan tersebut Alika memutuskan untuk masuk agama Hindu dengan beberapa alasan: (1) mengikuti agama yang dianut ayahnya karena ayah sebagai kepala keluarga tentu memiliki otoritas yang tinggi dalam memimpin keluarga dan (2) karena Ia tinggal di Bali dimana umat Hindu di Bali adalah mayoritas. Melihat kenyataan seperti itu, ibunya pun merelakan Alika memeluk agama Hindu meskipun ayahnya juga tidak memaksakanya untuk memeluk agama Hindu. Sebagaimana dikemukakan Alika dalam kutipan berikut.

"Dalam proses mencari kebenaran, dalam diriku pun sebenarnya hal itu sudah terjadi. Sejak kecil, aku yang memiliki orang tua yang berbeda agama ikut agama yang ayahku anut, yaitu Hindu. Alasannya jelas, pertama, ayahku adalah kepala keluarga. Walau bagaimanapun, otoritas dan kepemimpinan tertinggi dalam sebuah keluarga terletak dipundak seorang ayah, jadi aku ikut dengan keyakinan ayahku tersebut. Kedua, tentu saja karena kini aku tinggal di Bali. Umat Hindu di Bali adalah mayoritas, suasana Hindu begitu kental terasa. Hampir setiap sudut kota penuh dengan simbul-simbul atau aksen yang bernafaskan Hindu." (Lestari, 2015: 63).

Alika menginginkan agar orang-orang tahu bahwa tidak ada paksaan dari siapapun baginya untuk memeluk agama ini. Tidak ada tekanan dari ibu agar aku mau mengikuti agamanya, meskipun tak bisa dipungkiri ada beberapa masalah yang terjadi di keluarganya akibat ibu Alika terlihat memaksakan kehendaknya agar semua anakanaknya mengikuti agama yang dianutnya. Namun Alika memeluk agama ini bukan karena dipaksa.

Kisah Alika tersebut mencerminkan adanya kemerdekaan dalam anggota keluarga Alika untuk memeluk agama sesuai keyakinan masing-masing. Kedua orang tua Alika sama-sama memberikan bekal agama, ayahnya memberikan bekal agama Hindu dan ibunya memberikan bekal agama Kristen. Meskipun ketika masih di SD Alika dengan sukarela mengikuti agama ayahnya, ibunya juga tidak melarangnya. Upaya saling menghargai keyakinan atau agama antar anggota keluarga itulah patut menjadi tauladan bagi masyarakat Indonesia. Kepada anaknya saja orang tua tidak memaksakan 
kehendaknya untuk mengikuti keyakinannya, apalagi kepada orang lain. Oleh karena itu, perbedaan agama dalam keluarga ternyata bukan menjadi penghalang untuk menjalankan ibadahnya sesuai keyakinan masin-masing dalam keluarga guna mencapai kehidupan keluarga bahagia. Apalagi jika perbedaan agama tersebut terjadi antar keluarga, ataupun antar anggota masyarakat, seharusnya tidak menjadi masalah.

Kisah lain dalam Novel yang menunjukkan indahnya kehidupan dalam keanegaragaman agama terjadi di SD Negeri tempat Gugun, Alika, dan Naura sekolah. Pada jam pelajaran agama di sekolah tersebut siswa yang beragama Islam dikumpulkan dalam satu ruangan kelas untuk mendapatkan pelajaran agama Islam, sedangkan siswa yang beragama Hindu tetap di ruang kelas dan mendapat pelajaran agama Hindu, demikian siswa yang beragama Nasrani. Sebagaimana dikisahkan Alika dalam kutipan berikut.

"Seperti kebanyakan pendatang dari Pulau Jawa, Naura beragama Islam. Murid yang beragama Islam di sekolahku cukup banyak. Mereka menempati ruangan tersendiri saat pelajaran agama berlangsung. Jadi, saat jam pelajaran agama, temantemanku yang tidak beragama Hindu akan keluar dari ruangan kelas menuju ruangan khusus yang telah disiapkan oleh sekolah untuk belajar agama.”.” (Lestari, 2015:55).

Kisah tersebut mencerminkan adanya saling menghormati dan saling menghargai antar warga sekolah (guru dan siswa) terhadap siswa yang memiliki keyakinan agama yang berbeda. Sekolah mengembangkan kehidupan agama yang diyakini seluruh muridnya, sekolah mengkondisikan agar antar siswa saling mengakui eksistensi masing-masing agama.

Keharmonisan kehidupan di tengah-tengah perbedaan agama di Pulau Dewata Bali sebagaimana digambarkan di atas menjadi rusak setelah terjadinya ledakan bom Bali pada tgl. 12 Oktober 2002 oleh sekelompok orang yang mengatasnamakan Tuhan dalam menjalankan aksinya. Sebagaimana dikemukakan Lestari dalam kutipan berikut.

"Pada pukul 23.05 WITA, sebuah bom TNT sebesar $1 \mathrm{~kg}$. Meledak di Paddy"s Bar dan bersamaan dengan itu sebuah bom jenis RDX berbobot 50-150 kg. juga ikut meledak di Sari Club di Jalan Legian Kuta. Kehidupan malam yang terang benderang mendadak berubah menjadi kelabu, hentakan musik berganti menjadi isak tangis. Suara tawa dan rona bahagia lenyap, hilang bersama ceceran darah dan puing-puing bangunan. Toko-toko yang semula padat pengunjung, terang penuh lampu hiasan, sesak oleh keramaian, dikunjungi dengan tawa kebahagiaan, hancur dalam sekejap." (Lestari, 2015:86-87).

Dua ratus lebih nyawa manusia menjadi korban dalam peristiwa ledakan bom tersebut, kebanyakan warga Australia, sebagian lainnya adalah wisatawan asing dari Eropa dan Amerika. Warga lokal pun tidak sedikit yang turut menjadi korban.

Dampak ledakan tersebut Bali menjadi sorotan dunia, bukan saja karena keelokan alamnya, keindahan budayanya, melainkan karena 
telah menjadi makam 200 orang lebih yang kebanyakan wisatawan asing. Banyak wanita yang mendadak menjadi janda karena suaminya turut menjadi korban. Banyak wanita dan anak-anak kehilangan sumber pendapatan karena suami/ayah mereka sebagai tulang punggung ekonomi keluarga turut menjadi korban. Proyek-proyek bangunan besar dihentikan karena takut keamanan, hal ini mengakibatkan ribuan orang yang bekerja dalam proyek kehilangan pekerjaan. Pengamanan dilakukan dengan amat ketat, menyebabkan orang enggan datang ke Bali. Wisatawan asing pun juga takut datang ke Bali mengakibatkan perekonomian Bali semakin bertambah lumpuh. Begitu dasyat akibat ulah beberapa orang yang tidak menghargai perbedaan agama dan budaya.

Reaksi umat Islam di Pulau Bali atas bom Bali tersebut digambarkan oleh Lestari, seperti pada kutipan berikut.

"Siapa yang tak sedih tanah kelahirannya dihancurkan? Siapa yang rela saudaranya dibunuh tanpa alasan yang jelas? Dengan kejadian itu, kami pun merasa duka yang sama getrinya dengan mereka. Kami turut menderita dan kami turut dipersalahkan untuk hal yang tidak kami lakukan. Tapi, semua terlanjur terjadi. Kami tidak bisa menolak. Satu yang kami tahu, kejadian itu bukan hanya merenggut nyawa, bukan hanya merenggut masa depan para keluarga korban, melainkan juga mengancam perdamaian dan kebersamaan kami yang tinggal di Pulau Dewata." (Lestari, 2015:127).

Umat Islam di Bali turut berduka atas peristiwa tersebut, mereka turut dipersalahkan dan selalu dicurigai. Dengan demikian kedamaian dan kerukunan antar umat beragama benar-benar hancur akibat peristiwa bom Bali tersebut.

Gugun -etnis China yang beragama Konghucu-- terlihat cukup dewasa menanggapi bom Bali. Hal tersebut tampak pada kutipan berikut.

“...Tak ada yang menampik, sejak ditangkapnya pelaku, banyak yang memandang sinis terhadap agama mereka. Tapi aku tahu, itu bukan berarti semua orang yang seiman dengan mereka sama dengan mereka. Aku punya banyak teman dari berbagai kalangan dan agama. Bukan tipeku untuk memilih-milih teman berdasarkan agama yang mereka anut. Tak peduli apa agama mereka asal mereka baik dan menyenangkan, maka dengan senang hati aku akan berteman dengan mereka. Kejadian itu tidak akan mengubah apa pun dalam caraku memilih teman. Tapi, tidak dapat dipungkiri bahwa kejadian itu telah banyak mengubah cara pandang serta penilaian orang-orang." (Lestari, 2015:129).

Alika memberikan respon yang berbeda dengan Gugun. Sebagai penduduk Bali yang beragama Hindu wajar memberikan respon negatif atas peristiwa bom Bali tersebut. Hal tersebut tampak pada kutipan berikut. 
"Aku sendiri meskipun keluargaku tidak menjadi korban, tak pernah habis pikir, mengapa para pelaku melakukan perbuatan bejat seperti itu. Dari media aku mendengar alasan mereka melakukannya dengan alasan memperjuangkan agama mereka. Alasan yang sungguh tak masuk akal. Benarkan sebuah perjuangan harus mengorbankan begitu banyak nyawa yang tak tahu apa-apa? Sungguh aku tak paham jalan pikiran orang- orang tersebut." (Lestari, 2015:131).

Bukan hanya Alika yang memberi respon sangat negatif atas peristiwa bom Bali, Naura pun yang muslimah juga merespon sangat negatif. Sebab akibat bom Bali itu ayahnya tidak mendapatkan pekerjaan lagi. Ayah Naura yang bekerja sebagai mandor bangunan menjadi menganggur akibat bangunannya dihentikan karena takut keamanan setelah bom Bali meledak. Naura khawatir tidak dapat melanjutkan studi akibat peristiwa tersebut. Akibat lebih jauh, Naura menjadi ragu atas ajaran Islam yang selama ini ia percayainya karena belum mendapat jawaban atas pertanyaan-pertanyaan yang diajukannya sekaitan dengan kasus bom Bali tersebut. Hal tersebut tampak pada kutipan berikut.

"Setiap kali menangis memikirkan hal itu, aku selalu teringat si pelaku. Aku selalu teringat alasan-alasan mereka melakukan perbuatan tersebut, katanya untuk agama dan Tuhan mereka. Aku ingin sekali bertemu dengan mereka dan bertanya, Tuhan yang mana? Agama yang mana? Aku ingin tahu apa reaksi mereka saat melihat kondisi para keluarga korban yang ditinggal pergi anggota keluarganya gara-gara ulah mereka. ....Mengapa kami ikut terkena cap buruk dari masyarakat? Mengapa kami yang terkena imbas dan perlakuan tidak menyenangkan? Aku ingin tahu, sungguh ingin tahu. ....Dalam keingintahukanku tersebut, mulai muncul rasa ragu. Benarkan agama yang kupeluk ini mengajarkan hal tersebut?" (Lestari, 2015:133).

Kita mengetahui bahwa peristiwa bom Bali dilakukan oleh sekelompk teroris, yakni Amrozi Cs. dengan dalih sebagaimana dimuat di berbagai media untuk jihad. Naura juga memahaminya seperti itu, oleh karena itu ia mengajukan pertanyaan kepada Dosen Agama Islam Bpk. Putra dengan pertanyaan tentang arti jihad menurut Islam. Bpk. Putra memberikan beberapa jawaban tentang Jihad menurut Islam, seperti pada kutipan berikut.

"Jihad dalam memerangi orang-orang kafir itu ada etika dan syarat- syaratnya...... Jihad sendiri ada dua, pertama, jihad difa' atau defensif yang dilakukan untuk mempertahankan atau membela diri. Kedua, thalab atau jihad ofensif yang menyerang terlebih dahulu. Dalam jihad defensif, ketika umat Islam diserang oleh musuh, maka seluruh umat harus mempertahankan diri tanpa ada atau harus memenuhi syarat-syarat jihad. Tapi, melihat yang dilakukan oleh para teroris, mungkin mereka hendak melakukan jihad ofensif." (Lestari, 2015:172). 
Setelah mendengar penjelasan Bpk. Putra Naura mengajukan pertanyaan selanjutnya "Terus, apa syarat-syarat jihad, terutama jihad ofensif Pak?" Atas pertanyaan itu Bpk. Putra menjawab:

"Banyak, diantaranya jihad tersebut harus dipimpin oleh seorang kepala negara. Terus, mereka untuk berjihad harus mendapat ijin dari kedua orang tuanya. Dalam berperang pun kita tidak boleh melakukan pembakaran atau segala hal yang bersifat perusakan terhadap bumi, seperti menebang pohon. Selain itu, tidak diperbolehkan pula mengganggu apalagi membunuh wanita, anak-anak ataupun orang tua yang renta kecuali terpaksa." (Lestari, 2015:172).

Berdasarkan penjelasan itu, Naura mengajukan pertanyaan lanjutan "Seperti yang Bapak bilang tadi, jika kita diserang terlebih dahulu, bukankah kita harus melawan tanpa harus memperhatikan syarat-syarat jihad?". Jawaban Pak Putra atas pertanyaan tersebut adalah sebagai berikut.

“....Pernah baca ayat Al-Quran yang berbunyi, janganlah kamu mencela apa yang mereka sembah selain Allah, niscaya mereka akan membalas memaki Allah berlebih-lebihan tanpa dasar ilmu. Sudah jelas kan maksud ayat Al-Quran itu?" (Lestari, 2015:173).

Akhirnya Naura menyimpulkan "Jadi, yang mereka lakukan bukan jihad yang dimaksud dalam Islam, kan?” (Lestari, 2015:171).

Makna yang dapat diambil dari peristiwa ledakan bom Bali dan diskusi antara Naura dengan dosennya tersebut: (1) Tindakan terorisme yang dilakukan mengatasnamakan Islam dapat merusak kepercayaan umat Islam secara keseluruhan; (2) Alasan jihad sebagai motivasi teroris melakukan pengeboman tidak dibenarkan menurut Islam; (3) Pendidikan agama Islam harus dilakukan secara benar, komprehensif, sehingga tidak menghasilkan lulusan yang salah dalam memahami arti jihad sebagaimana pelaku bom Bali; (4) Para pengusaha penyedia jasa layanan wisatawan asing, baik penyedia bar, diskotik, ataupun jasa lainnya hendaknya mempertimbangkan moral umat Islam yang kebetulan menjadi mayoritas di Indonesia dalam mengembangkan usahanya. Mungkin tempatnya merupakan tempat tertutup dan khusus untuk wisatawan asing serta selektif dalam menerima pengunjung atau konsumen baik wisatawan asing maupun domistik, sebab hal ini juga merupakan bentuk dari menghargai nilai-nilai agama Islam yang mayoritas dianut oleh penduduk Indonesia; (5) Meskipun kedatangan wisatawan merupakan sumber pendapatan negara, namun Pemerintah seyogyanya lebih ketat dalam mengontrol pengusaha jasa diskotik, bar, dan lainnya dalam menjalankan usahanya agar tidak sampai memancing amarah sebagian umat Islam dan umat beragama lain yang tidak menyukainya. Disamping itu seyogyanya keamanan dan kenyamanan wisatawan lebih diperhatikan lagi sehingga Bali tetap menjadi surga bagi wisatawan namun tidak sampai merusak kerukunan antar umat beragama. 
Seiring dengan perjalanan waktu setelah bertahun-tahun bom Bali berlalu akhirnya kerukunan antar umat beragama kembali pulih meski belum sepenuhnya. Hal itu dirasakan oleh Naura dalam kehidupan di kampusnya. Ia sehari-hari mengenakan kerudung dan membawa perlengkapan sholat ke kampus, seperti mukena dan sajadah. Ketika waktu sholat tiba dan perkuliahan sedang berlangsung, bahkan saat ujian sekalupun ia tidak segan-segan minta ijin ke dosennya yang hampir semuanya beragama Hindu untuk melakukan sholat. Semua dosennya mengijinkan. Bahkan ketika perkuliahan terjadi pada saat waktu sholat mahgrib tiba, teman-teman Naura yang beragama Hindu mengingatkannya untuk melakukan sholat mahgrib. Hal tersebut tampak pada kutipan berikut.

"Bisa berteman dengan orang-orang yang memiliki kesamaan dengan kita adalah sebuah anugerah, tapi bisa menjalin pertemanan dengan orang-orang yang berbeda dengan kita itu indah. Kini, setiap hari aku membawa perlengkapan sholat dari sajadah hingga mukena. Saat jam sholat aku akan meminta ijin kepada dosenku untuk menunaikan sho lat. Di kampusku memang tidak ada musholla, tapi itu tidak menjadi alasan bagiku untuk tidak menunaikannya. Untuk berwudhu kugunakan kamar mandi kampus. Untuk sholat biasanya aku mencari tempat yang kosong. Apabila tidak ada, aku tidak segan untuk sholat di gudang kamera dan alat-alat. ........Dosenku hampir seluruhnya Hindu, tapi mereka selalu mengijinkanku untuk melaksanakan ibadah sholat, bahkan di saat jam ujian sekalipun. Bagaimana dengan teman-temanku? Mereka adalah teman-teman yang luar biasa. Sejak aku menggunakan kerudung, teman-temanku semakin menunjukkan kepedulian serta rasa hormatnya padaku. Di saat aku kuliah malam dan memasuki jam sholat mahgrib, mereka akan mengingatkanku untuk melaksanakan ibadah sholat." (Lestari, 2015:205-206).

Keindahan hidup dengan teman-teman yang berbeda agama terus dinikmati oleh Naura di kampusnya. Teman-temannya yang beragama Hindu memperhatikan Naura sampai pada masalah najisnya air liur anjing bagi umat Islam dan makanan yang dilarang Islam, yakni daging babi.

Naura memiliki teman bernama Satrya yang asli Bali dan memiliki banyak kamar untuk kos yang kebetulan penghuni kos semuanya muslim. Ketika Naura bertanya "mengapa anjingmu tidak kau lepas saja?" Satriya menjawab "kamu tahu sendiri kan, yang kos di rumahku semuanya muslim. Nanti kalau kulepas, anjingku bisa mengganggu mereka, berarti aku yang salah." (Lestari, 2015:205-210).

Naura pernah tidak diajak teman-temannya untuk makan bersama di resturant dan setelah Naura memandang teman yang mentraktirnya, Andika, ia mendekat ke Naura dan mengatakan: "Ra, kamu jangan ikut ya. Di sana menunya banyak yang pakai babi. Ada sih yang gak pakai, tapi lebih baik jangan." (Lestari, 2015:211).

Contoh keharmonisan hidup Naura dengan teman-teman yang berbeda agama di kampusnya itu cukup menghibur kita yang mendambakan kerukunan dan kedamaian. Sebab begitu banyak di 
media berita tentang konflik, baik seagama, antar agama, suku, maupun diskriminasi terhadap satu golongan. Mereka saling serang, saling menghujat, bahkan tak jarang saling membunuh. Seolah paling membenarkan kelompoknya sendiri, mereka lupa bahwa ada kelompokkelompok lain yang hidup dan ada di sekeliling mereka. Sebenarnya wajar merasa kelompok kita paling benar, toh ini masalah keyakinan masing-masing. Terkadang satu keyakinan tidak bisa dijelaskan dengan seribu kata sekalipun. Tapi, bukanlah kurang ajar jika memaksakan kelompok lain menjadi sama dengan kelompok kita.

"Perlakukanlah orang lain seperti kamu ingin diperlakukan. Jika tak ingin dipaksa, maka jangan memaksa. Perbedaan itu begitu nyata, tak bisa kita paksa jadi sama. Aapanya yang sama jika dalam berpakaian pun kita punya selera masing-masing. Lantas, mengapa harus pura-pura menjadi sama? Bukankan pelangi terlihat indah karena warnanya yang berbeda-beda? (Lestari, 2015:205).

\section{Nilai Pendidikan Menghargai Perbedaan Ras}

Nilai pendidikan menghargai perbedaan Ras yang terkandung dalam novel Different tercermin pada cerita tokoh yang memiliki perbedaan fisik mencolok dengan tokoh lain dalam novel tersebut, yakni Gugun (Gunawan). Ia satu-satunya siswa yang berkulit putih, mata sipit, etnis China, dan agama Konghucu di SD Negeri tempat tokoh Naura dan Alika sekolah. Semula teman-teman Gugun beranggapan bahwa Gugun dan orang tuanya memiliki budaya seperti etnis China pada umumnya, yakni pelit, pilih-pilih dalam berteman, dan antarjemput pakai mobil pribadi. Ternyata anggapan itu tidak benar. Gugun adalah etnis China yang ramah, murah senyum, tidak pilih-pilih dalam berteman, suka memberi makanan ringan bermerk dari toko makanan keluarganya, dan lebih senang naik angkot ketimbang antar-jemput dengan mobil pribadi.

Gugun tidak mengalami kesulitan dalam bergaul dengan temantemannya. Sebagaimana digambarkan oleh pada kutipan berikut.

"Awalnya, aku mengira jika orang-orang berkulit putih dan bermata sipit seperti dia pasti akan berlagak sombong, bahkan cenderung pemilih dalam mencari teman. Tapi semua perkiraanku salah, Gugun semakin menarik karena dia sangat ramah dan senang tersenyum pada orang-orang di sekitarnya. Dia tak pernah membatasi diri dalam pergaulannya. Dia bisa berteman dengan siapa saja. Sifatnya yang ramah itu tentu saja makin membuatnya terlihat menarik di mata kami, temantemannya. Sayangnya Gugun tidak sekelas dengan saya, tetapi sekelas dengan Alika" (Lestari, 2015:38-39).

Gambaran Gugun sebagaimana dideskripsikan Naura di atas menunjukkan bahwa (1) Gugun berhati mulia, memandang perbedaan Ras bukan menjadi penghalang dalam berinteraksi dengan teman-teman etnis Jawa dan Bali. Demikian orang tua Gugun yang memperkenankan Gugun bersekolah di SD Negeri yang didominasi anak-anak Jawa dan Bali. Sikap Gugun dan orang tuanya itu patut menjadi tauladan bagi 
seluruh warga bangsa Indonesia bahwa meskipun etnis minoritas asalkan dapat beradaptasi dengan budaya etnis mayoritas maka perbedaan suku dan ras bukan menjadi penghalang dalam bergaul dan mencapai cita-cita; (2) Sikap Naura, Alika, dan teman-teman sekelas Alika terhadap Gugun juga layak menjadi tauladan. Mereka menerima dengan tulus berteman dengan Gugun tidak dilihat karena etnis Chinanya, juga bukan karena Gugun gemar memberi makanan ringan, tetapi karena kemampuan Gugun dalam bergaul dengan temantemannya. Jadi menilai orang jangan dari etnis atau Rasnya, tetapi dari kualitas pribadi dan kemampuannya dalam berinteraksi dengan sesama.

Keindahan berteman dalam keragaman etnis atau Ras dan agama seperti itu terus berlanjut sampai mereka bertiga kuliah di perguruan tinggi. Hal tersebut sebagaimana digambarkan Naura pada kutipan berikut.

"Disini tengah duduk seorang perempuan dengan kerudung bersama teman-temannya, seorang gadis dengan kalung berliontin Salib (Alika yang berpindah agama dari Hindu ke Nasrani setelah dewasa), seorang pemuda keturunan China (Gugun). Kami bertiga berbeda, tetapi kami tahu perbedaan itu tak pernah menjadi penghalang bagi kami untuk berteman. Justru kami terlihat indah dengan perbedaan yang begitu mencolok itu. Dengan perbedaan diantara kami, kami belajar saling menghargai dan menghormati." (Lestari, 2015:222).

\section{Nilai Pendidikan Menghargai Perbedaan Budaya}

Sebagaimana telah diuraikan, bahwa ditinjau dari latar belakang budaya tokoh- tokoh utama dalam novel, ketiga tokoh utama memiliki budaya yang berbeda seiring dengan perbedaan agama yang dipeluk dan asal daerah masing-masing. Naura berasal dari keluarga yang datang dari Jawa. Oleh karena itu agamanya pun seperti yang dipercaya oleh orang Jawa pada umumnya, yakni Islam. Sebagai keluarga muslim, Naura dan keluarganya menjalankan syareat Islam dan menjauhi larangan-larangan dalam Islam, termasuk tidak menggunakan jilbab, makan daging babi, dan bergaul secara bebas. Sebagai keluarga yang orang tuanya berasal dari Jawa, maka budaya Jawa pun tidak bisa dilepaskan. Satu diantaranya beranjang sana ke sanak keluarga di Jawa (mudik) saat lebaran idhul fitri tiba.

Sikap menghargai perbedayaan budaya ditunjukkan oleh temanteman kuliah Naura ketika Naura hari pertamanya memakai hijab (jilbab) ke kampus. Naura khawatir akan menjadi pembicaraan dan ejekan teman-temannya di kampus, kok bisa anak tomboi berubah drastis menjadi anak yang sholehah dilihat dari pakainnya yang mengenakan hijab. Ternyata kekhawatiran Naura tidak terbukti, temantemannya menghargai Naura. Hal itu tercermin dalam pernyataan Naura sebagai berikut.

"Ternyata kekhawatiranku akan sikap teman-temanku tidak terbukti. Banyak dari mereka yang berkomentar, tapi semuanya hanya komentar- komentar gurauan. Mereka bahkan tidak bertanya apa-apa padaku. Hanya ada senyum lebar dan candaan 
karena tidak menyangka seorang perempuan berpenampilan tomboi mampu merubah penampilannya begitu drastis." (Lestari, 2015:165).

Keheranan Naura atas sikap teman-teman yang tidak mengejeknya itu didasarkan bahwa kampusnya adalah bukan perguruan tinggi Islam, juga bukan perguruan tinggi Hindu, bahkan banyak mahasiswa etnis China yang tentunya beragama Konghucu dan Kristen. Hal tersebut tercermin dalam kutipan berikut.

"Kampusku bukanlah kampus Islam, kampusku juga tidak didominasi oleh mahasiswa beragama Hindu seperti kampuskampus lainnya di Bali. Di kampusku justru banyak ditemukan mahasiswa dengan wajah dan potongan seperti Gugun. Ya, etnis Tionghoa banyak ditemukan di kampusku, meskipun di kelasku sendiri hanya ada satu orang China, yaitu Pita. Makanya, pemandangan seorang wanita yang berhijab menjadi pemandangan yang begitu langka. Bahkan diangkatanku saja hanya ada dua orang yang berhijab dan kehadiran mereka jelas menyolok diantara mahasiswa lainnya." (Lestari, 2015:165-166).

Berbeda dengan Naura, Alika berasal dari Kalimantan. Ayahnya memeluk agama Hindu dan ibunya Nasrani. Setelah migrasi ke Bali karena alasan pekerjaan orang tuanya, Alika semakin cenderung mengikuti ayahnya, yakni memeluk agama Hindu. Namun setelah beranjak dewasa ternyata Alika kemudian secara sukarela pindah agama, mengikuti jejak ibunya, yakni Nasrani. Alika menjalankan dua budaya, ketika belum dewasa menjalankan budaya sebagaimana diajarkan agama Hindu, turut merayakan hari raya ngaben, galungan, dan nyepi. Turut beribadah di Pure bersama teman-temannya di SD ketika pelajaran agama Hindu berlangsung. Setelah kuliah, Alika bersedia di Baptis oleh pendeta gereja tempat ibunya beribadah. Sejak itulah Alika bersama ibunya menjalankan budaya atau ajaran Kristen, baik dalam berhubungan dengan Tuhan maupun dalam berinteraksi dengan sesama. Ketika hari raya Hindu tiba, biasanya Alika membantu nenek (dari ayah) membuat canang-canang untuk persembahyangan penganut Hindu dan merangkai janur sebagaimana budaya orang Bali dalam merayakan hari raya Hindu, setelah Ia masuk Kristen, meskipun ia ingin membantunya, merasa tidak enak dengan ibunya yang memegang teguh budaya ajaran Kristen. Hal ini terungkap dalam pernyataannya berikut.

"Sulit, itu kata yang tepat untuk menggambarkan kondisiku sekarang. Tahun lalu aku masih membantu nenek membuat canang-canang itu untuk persembahyangan. Sekarang, aku hanya bisa diam melihatnya kerepotan merangkai semua janur itu seorang diri. Bukannya aku tak mau membantu, tapi aku bingung, masih layakkah aku membantunya? Yang paling penting, masih maukah dia menerimaku untuk membantunya? (Lestari, 2015:178).

Gugun memiliki budaya tersendiri dibanding teman-temannya di SD. Ia setia mengikuti ajaran Konghucu sebagaimana agama kedua 
orang tuanya. Sebagai orang China, Gugun juga turut aktif bersama kedua orang tuanya melestarikan budaya China. Perbedaan budaya dari ketiga tokoh utama dalam novel tersebut ternyata bukan menjadi penghalang bagi mereka bertiga dalam menjalin pertemanan dan persaudaraan. Keakraban mereka berlanjut sampai di perguruan tinggi. Bahkan teman-teman Naura yang beragama Hindu begitu menghargai Naura, diantaranya Andika dengan tidak mengajaknya di rumah makan yang masakannya mengandung daging babi. Teman-teman kuliahnya yang beragama Hindu juga sering mengingatkan Naura untuk menjalankan sholat ketika waktu sholat tiba. Dosennya yang juga kebanyakan beragama Hindu mengijinkan Naura untuk melaksanakan sholat ketika ia meminta ijin untuk sholat. Hal tersebut seperti yang dikemukakan Naura dalam kutipan berikut.

“....Dosenku hampir seluruhnya Hindu, tapi mereka selalu mengijinkanku untuk melaksanakan ibadah sholat, bahkan di saat jam ujian sekalipun. Bagaimana dengan teman-temanku? Mereka adalah teman-teman yang luar biasa. Sejak aku menggunakan kerudung, teman-temanku semakin menunjukkan kepedulian serta rasa hormatnya padaku. Di saat aku kuliah malam dan memasuki jam sholat mahgrib, mereka akan mengingatkanku untuk melaksanakan ibadah sholat." (Lestari, 2015:206).

Uraian diatas menggambarkan betapa indahnya hidup rukun, saling menghargai, saling menghormati, dan saling membantu diantara kita meskipun terdapat berbagai perbedaan budaya. Perbedaan memang sudah menjadi kodrat yang Kuasa. Oleh karena itu perbedaan sudah seharusnya bukanlah menjadi penghalang bagi kita untuk mencapai citacita.

Berbagai kisah beberapa tokoh dalam Novel Different mencerminkan sikap saling menghargai dan saling menghormati dalam memenuhi kebutuhan kehidupan meskipun diantara mereka berbeda suku, agama, ras, dan budaya sebagaimana telah dideskripsikan di atas menggambarkan bahwa Indonesia memang terbangun dari struktur Negara bangsa (nation state) yang tidak dapat menghindari dari keniscayaan kemajemukan (pluralisme) (Nugroho, 1999:129). Sejarah telah menorehkan realitasnya melalui wujud kemerdekaan keindonesiaan sebagai hasil bahu-membahu dari kekuatan kemajemukan yang dimiliki bangsa ini. Dalam prinsip dasar demokrasi, kemajemukan (pluralitas) menjadi sebuah fenomena kunci, sebab hakikat berdemokrasi dalam sebuah Negara bangsa ada pada transformasi nilai dari heterogenitas teritorial, sosial (SARA), budaya ke dalam bentuk homogenitas polit ik sebagai konsensus untuk berada bersama-sama dalam sebuah bangsa demi mencapai tujuan bersama yang di dalamnya ada hak dan kedudukan yang sama, ada saling pengakuan terhadap keberadaan masing-masing elemen. Perbedaan dalam bentuk heterogenitas tersebut hanya akan menjadi sebuah potensi kolektif jika telah terwujud dalam konsensus tujuan hidup bersama dengan jaminan tidak akan ada pengingkaran terhadap salah satu unsur. Ketika terjadi pengingkaran terhadap salah satu unsur, 
pemberontakan nilai akan terlihat lewat berbagai ekspresi yang fenomenanya kini semakin tampak di Indonesia.

\section{SIMPULAN}

\section{DAFTAR PUSTAKA}

Al-,Attas, Syed Muhammad Naquib. 2010. Islam dan Sekularisme. Alih bahasa oleh Khalif Muammar, Usep Muhammad Ishaq, dkk. Bandung: Institut Pemikiran Islam dan Pengembangan Insan (PIMPIN)

Al-Malaky, Ekky. 2004. Remaja Doyan Nonton: Why Not?. Bandung: Dar! Mizan.

Al-Ma"ruf, Ali Imron. 2009. "Metode Penelitian Sastra: Sebuah Pengantar". Hand Out Kuliah. Surakarta: FKIP - UMS

Al-Ma"ruf, Ali Imron. 2006. Dimensi Sosial Keagamaan dalam Fiksi Indonesia Modern. Surakarta: Smart Media

Banks, James A.; Cherry A. McGee Banks (editors). 2001. Handbook of Research on Multicultural Education (Second Edition). SanFrancisco: Jossey-Bass.

Binti Salimah. 2011. "Novel Eliana Karya Tere-Liye: Kajian Isi dan Metode Pendidikan Islam”. Skripsi. UIN Sunan Kalijaga Yogyakarta. Brahim. 1968. Drama dalam Pendidikan. Jakarta: Asia Timur Baru.
Gani Rizanur. 1988. Pengajaran Sastra Indonesia (Respon dan Analisis). Jakarta: Depdikbud.

Hadikusumo, dkk. 1999. Pengantar Pendidikan. Semarang: CV.Ikip Semarang Press.

Hardaniwarya, Robert. 2001. Dialog Umat Kristiani dengan Umat PluriAgama/Kepercayaan di Nusantara, Yokyakarta: Kanisius.

Heru Nugroho, 1999. "Konstruksi SARA, Kemajemukan dan Demokrasi." Jurnal UNISIA No.40/XXII/IV, Yokyakarta: UII.

Isre, Moh Soleh. 2003. Konflik Etno Religius Indonesia Kontemporer, Jakarta: Depag RI.

Lathief, Supaat I. 2008. Sastra: Eksistensialisme - Mistisisme Religius. Lamongan: Pustaka Ilalang

Lestari, Irma T. 2015. Different: Ketika Perbedaan Bukan Sebuah Penghalang. Solo: Tinta Medina.

Madjid, Nurcholis. 1999. Civil Society Versus Masyarakat Madani, Bandung: Pustaka Hidayah.

Milles M, B dan Michaell H. 1992. Analisis Data Kulitatif. Jakarta: Universitas Indonesia Press. 
Nugraheni, Sekar. 2007. "Aspek Sufistik dalam Kumpulan Cerpen Setangkai Melati di Sayap Jibril Karya Danarto: Tinjauan Semiotik". Skripsi. Universitas Muhammadiyah Surakarta

Nurgiyantoro, Burhan. 2007. Teori Pengkajian Fiksi. Yogyakarta: Gadjah Mada University Press.

Pradopo, Rachmat Djoko. 2008. Beberapa Teori Sastra, Metode Kritik, dan Penerapannya. Yogyakarta: Pustaka Pelajar.

Ratna, Nyoman Kutha. 2008. Teori, Metode, dan Teknik Penelitian Sastra. Yogyakarta: Pustaka Pelajar.

Razak, Abdul. 1990. Kalimat Efektif Struktur, Gaya dan Variasi. Jakarta: Gramedia. Scoot. 1980. Current Literary Term, Aconcise Dictionary. London: The Macmilland Press.

Semi, Atar. 1993. Metode Penelitian Sastra. Bandung: Angkasa.
Siswantoro. 2010. Metode Penelitian Sastra. Yogyakarta: Pustaka Pelajar

Stanton, Robert. 2007. Teori Fiksi (Terjemahan oleh Sugihastuti). Yogyakarta: Pustaka Pelajar.

Suwondo, dkk. 1994. Nilai-nilai Budaya Susastra Jawa. Jakarta: Depdikbud. Tarigan, Hendri Guntur. 1984. Prinsip-prinsip Dasar Sastra. Bandung: Angkasa.

Suwondo, dkk. 1987. Pengajaran Wacana. Bandung: Angkasa.

Waluyo, Herman J. 2003. Drama (Teori dan Pengajarannya). Yogyakarta: Hanindita.

Wellek, Rene dan Warren, Austin. 1993. Teori Kesusastraan. Jakarta: Gramedia. 